\title{
Food items of Macrotus waterhousii (Chiroptera: Phyllostomidae) in central Mexico
}

\author{
Óscar Sánchez ${ }^{* 1}$ and Don E. Wilson ${ }^{2}$
}

\author{
${ }^{1}$ Las Flores, San Lorenzo Tepaltitlán 50018, Estado de México, México. E-mail: teotenango@yahoo.com (OS) \\ ${ }^{2}$ Division of Mammals, National Museum of Natural History, Smithsonian Institution, Washington, D.C., EE. UU. E-mail: wilsond@ \\ si.edu (DEW) \\ *Corresponding author
}

\begin{abstract}
Macrotus waterhousii is a phyllostomid bat whose diet is poorly known, particularly in semiarid and temperate central Mexico. In this work additional information is reported from food remains discarded by this bat, including taxonomic composition, frequencies and size range of consumed insects; the assessment of a prediction on prey hardness of food insects, at the ordinal level; relative energy reward of insect prey in the sample; a comparison of the composition of the food sample from the arid study locality against one from a subtropical-temperate site; and brief comments on the known ecological importance of particular prey in the arid site. A sample of insect food remains discarded by Macrotus waterhousii bulleri, was recovered from under a roost in semiarid northern Querétaro, Mexico. The taxonomic identity, estimated relative abundance, size, hardness, and ecological relations of prey species in the sample were studied and results were compared with reference to feeding ecology. A comparison of the data with available information on food taken by Macrotus waterhousii mexicanus in temperate-subtropical central Mexico was made. Information on the importance of the most relevant identified insects was extracted from literature and analyzed. In Querétaro, Lepidoptera, Hymenoptera, and Coleoptera were frequent; moths dominated but, as a single species, the (winged) ant, Atta mexicana was most frequent. Nocturnal insects were frequent; diurnal ones may have been gleaned at night. A sample from Estado de México featured Orthoptera, Coleoptera, and Lepidoptera. Wingspan range of frequent prey in Querétaro was $25-80 \mathrm{~mm}$, but moths over $70 \mathrm{~mm}$ were over one fifth of the sample. Prey hardness estimation was similar to that for Macrotus californicus. Some insects identified are of ecologic and agricultural relevance. Insects known to be seasonally abundant in the environment were also abundant in the sample, presumably captured according to that availability. However this bat, aside from eating insects of moderate size in proportion to its jaw size, is also capable of capturing large moths and these may represent a significant energy intake. Most insects are nocturnal species. The taxonomic composition of the food samples from both areas suggests that $M$. waterhousii (sensu lato) may be mostly an opportunistic predator. Local insect fauna composition and dynamics may be hypothesized to influence food taken by M. waterhousii. Several insect species consumed by this bat in semiarid Querétaro have crucial roles in the ecology of arid land vegetation, as well as some economic importance for agriculture as pests.
\end{abstract}

Macrotus waterhousii es un murciélago filostómido cuya dieta se conoce pobremente, particularmente en áreas semiáridas y templadas del centro de México. Este trabajo aporta información adicional a partir de restos de alimentos descartados por este murciélago incluyendo: composición taxonómica, frecuencias e intervalo de tamaño de los insectos consumidos; evaluación de una predicción sobre dureza de presas al nivel de órdenes entomológicos; recompensa energética relativa de los insectos en la muestra; una comparación de la composición de la muestra de restos alimenticios del sitio árido con una de un sitio subtropical-templado; y comentarios breves sobre la importancia ecológica de presas particulares en el sitio árido. Se recuperó una muestra de restos de insectos descartados por Macrotus waterhousii bulleri bajo un refugio en el norte semiárido de Querétaro, México. Se estudiaron la identidad taxonómica, la abundancia relativa estimada, el tamaño, dureza estimada y relaciones ecológicas de los insectos presa y se contrastaron los resultados en referencia a la ecología de la alimentación de este quiróptero. Se compararon los resultados con información disponible sobre alimentación de Macrotus waterhousii mexicanus en un sitio templado-subtropical de México central. Se extrajo y estudió información de literatura sobre la importancia de los insectos más relevantes en la muestra. En Querétaro fueron frecuentes Lepidoptera, Hymenoptera y Coleoptera; dominaron las mariposas nocturnas pero la hormiga Atta mexicana fue la más frecuente. Predominaron insectos nocturnos; los diurnos pudieron ser recogidos posados, por la noche. Un reporte del Estado de México incluyó Orthoptera, Coleoptera y Lepidoptera. La envergadura de presas frecuentes en Querétaro fue de $25-80 \mathrm{~mm}$, pero más de una quinta parte fueron mariposas nocturnas de más de $70 \mathrm{~mm}$. La dureza estimada de presas es similar a la de Macrotus californicus. Algunos de los insectos identificados tienen relevancia ecológica o en la agricultura. Insectos que se sabe son abundantes estacionalmente en el ambiente fueron también abundantes en la muestra, presumiblemente capturados conforme a esa disponibilidad. Sin embargo, este murciélago, además de alimentarse de insectos de tamaño moderado en proporción al tamaño y estructura de sus mandíbulas, también es capaz de capturar mariposas nocturnas grandes y éstas pueden representar in ingreso significativo de energía. La mayoría de los insectos son especies nocturnas. La composición taxonómica de las muestras de restos de alimento en ambos sitios sugiere que $M$. waterhousii (sensu lato) puede ser principalmente un depredador oportunista. Puede formularse la hipótesis de que la composición local de la fauna de insectos y su dinámica influyen en el alimento tomado por $M$. waterhousii. Varias especies de insectos consumidos por este murciélago en la parte semiárida de Querétaro tienen papeles cruciales en la ecología de la vegetación árida, así como cierta importancia económica para la agricultura, como plagas. 
Key words: diet, Estado de México, insectivory, Macrotus waterhousii, Querétaro.

(c) 2016 Asociación Mexicana de Mastozoología, www.mastozoologiamexicana.org

\section{Introduction}

The chiropteran genus Macrotus comprises two species: M. waterhousii (western, central and southern Mexico, Guatemala, and the Antilles; Simmons 2005; Medellín et al. 1997), and M. californicus (southwestern United States of America, the Baja California Peninsula and Sonora, Mexico, Simmons 2005). Within the former taxon, the subspecies M. w. bulleri inhabits western and central Mexico, while M. w. mexicanus occurs from the Mexican Transvocanic Belt south to Chiapas and Yucatan (Jones and Carter 1976). Other subspecies of M. waterhousii are known from the West Indies (Jones and Carter 1976).

Generally, during the day individuals of $M$. waterhousii rest in thermally stable caves, tunnels, or mines, and during nocturnal activity may carry their prey to places where they can perch and eat without disturbance, much as has been observed for its sister species M. californicus (Bell et al. 1986). Insects are not consumed in their entirety; less edible parts are discarded and exoskeletal remains, such as wings and legs, are dropped to the ground in the process (Wilson 1973; Gardner 1977; Dunkle and Bellwood 1982). Despite this favorable circumstance for dietary studies, there are few analyses of samples of such remains for M. waterhousii.

Macrotus waterhousii and M. californicus are mainly insectivorous, and at least the latter has been reported to have an energetically austere pattern of foraging that relies on visual prey location (Bell 1985; Bell and Fenton 1986; Bell et al. 1986). Recent evidence indicates low intensity, frequency modulated echolocation capabilities for M. waterhousii (Murray et al. 2009); however, three-dimensional echolocation approach to prey needs to be investigated, as it can be an important feature for recognition of night-perching prey in total darkness.

The composition of food taken by M. waterhousii is not sufficiently documented. Considered a mainly insectivorous species, for more than a century it has remained unclear if fruit consumption is merely casual or more purposeful (Dobson 1878). Another report of fruit consumption by $M$. waterhousii is available from Jamaica (Osburn 1865, quoting his informants).

Insects, particularly Odonata, have been cited as food for M. waterhousii (again, along with some evidence of fruit; Gardner 1977). Other available information is as follows: In the Turks \& Caicos Islands of the Antilles, McCarthy (1982) found M. w. waterhousii capturing giant cockroaches, tettigoniids and large Erebus moths. In Mexico there is one report of insect remains left by M. w. mexicanus in a site with deciduous tropical forests within the Rio Balsas Basin (Guerrero), which included mainly orthopterans of the genus Microcentrum (Tettigoniidae), and noctuid moths (Erebus sp., Villa-Ramírez 1967); interestingly, several noctuid moths (Erebus is now placed in the family Erebidae) are well known for their habit of ceasing wing beats during flight in response to the presence of foraging insectivorous bats (Hoy 1992). More recently, in Jamaica, M. waterhousii was reported feeding mainly on Lepidoptera, then Diptera, and Coleoptera, as determined by molecular sequencing of faecal samples (Emrich et al. 2013). 
Barboza-Eguiluz and Bernal-Jiménez (1992) recorded the composition of insect remains at the order-level in a sample collected by one of us (Ó. Sánchez) under a refuge of M. W. mexicanus in Nanchititla, SW Estado de México, Mexico. These authors reported the orders Orthoptera, Coleoptera, Lepidoptera, Hemiptera, and Odonata.

The other species of the genus, M. californicus, very similar in size and structure to $M$. waterhousii, is known to capture insects both in flight and perched on exposed twigs, or even on the ground (Bell and Fenton 1986). Some insects have been documented to rest in this way (Williams 1935) but others must be captured in full flight and, furthermore, some moths are known to depend on swift, low-altitude air currents, especially those associated with night thermal inversions (Beerwinkle et al. 1994). These and other factors can influence actual food availability for bats such as both species of Macrotus.

Known insect prey of $M$. californicus include acridid and tettigoniid orthopterans, cerambycid and scarabaeid beetles, as well as caterpillars and adults of noctuid and sphingid moths; this bat also has been documented to consume wild fruit, at least on occasion (Ross 1967; Gardner 1977). In Arizona, M. californicus was found to feed on grasshoppers, tettigoniids, cerambycid beetles, cicadid homopterans, and sphingid and noctuid moths; as well as fruit of some cactus species (Hoffmeister 1986). Ross (1967) reported large Orthoptera, Coleoptera, and Lepidoptera as prey of M. californicus in Arizona and California.

Freeman (1981) analyzed correspondence of jaw and teeth morphology (jaw thickness, canine length, molar size, and extent of reduction of $\mathrm{M}^{3}$ ) and relative hardness of food consumed by several insectivorous bats, measured with a categorical, conventional scale from 1 to 5 applied to insect orders, and determining the average hardness of prey (hereafter $\mathrm{AH}$ ). Scores assigned by Freeman to prey insect Orders reported by Ross (1967) as food of $M$. californicus resulted in an intermediate AH. Information on this aspect is lacking for M. waterhousii.

Optimal diet theory (Sih and Christensen 2001) would predict that under closely similar availability, larger prey might be favored in terms of a greater energetic compensation for the predator. Nevertheless, a combination of pursuit and subduing costs (Griffiths 1980) must be taken into account. On the other hand some insects are highly seasonal, and this limits their availability as prey (Williams 1935; Tuskes et al. 1996); and even behavioral trends of others also tend to exert a counterbalancing influence. Factors like these render this theory controversial in certain cases. On the other hand, recently, Segura-Trujillo et al (2016) analyzed diet reports for a variety of Nearctic and Neotropical bats, and concluded that feeding guilds in bats may be better understood if approached considering also prey flying abilities and exoskeletal hardness. Although no species of Macrotus was included in that study, its classical allocation as a gleaner will probably need to be reviewed when more information on its diet is available.

In this respect, Dunkle and Bellwood (1982) stated that there was no conclusive evidence for opportunism versus preference for particular prey taxa below the order and family levels, or for prey-size range for M. waterhousii.

Some species of various insect orders known to be preyed upon by Macrotus spp. can be relevant for foliar dynamics (Smith 1963; Mintzer 1979) and for plant life cycles (Deloach and Cuda 1994). Other arthropod species pursued by various insectivorous bats can be of potential importance for agriculture (McCracken 1996). 
The present work presents additional, more detailed evidence on the diet of M. waterhousii bulleri, based on a sample of food remains found under a roost in a locality of arid central Mexico. It aims to: a) describe the taxonomic composition of prey as close as possible at the species level, and estimate their frequencies; $b$ ) evaluate the size range of prey in the sample; $\mathrm{c}$ ) test the prediction of intermediate prey hardness $(\mathrm{AH})$ at the order level, derivable for $M$. waterhousii from Freeman's (1981) hypothesis; d) indicatively compare relative energy reward of insect prey in the sample; e) compare overall composition of the food sample from the arid locality against one from a subtropical-temperate site; and f) briefly comment on the known ecological importance of particular prey in the arid site.

\section{Materials and methods}

The study site in Peña Blanca, Querétaro. The abandoned mine is located $500 \mathrm{~m}$ E Peña Blanca, Querétaro, Mexico (lat 21.0454, long -99.7473; 1360 m; Figure 1). The mine follows a very slightly inclined course, at least to where the $M$. w. bulleri were roosting. Vegetation around the opening of the mine is semiarid scrub and features Acacia vernicosa, A. schaffneri, Fouquieria splendens, Mimosa spp., Karwinskia mollis, Prosopis laevigata, Opuntia spp. and Agave lecheguilla, among other plants (see also Zamudio 1984). A small temporary arroyo exists near the entrance of the mine.

The comparative site in Nanchititla, Estado de México. This locality is the vicinity of the present-day Estación Biológica Sierra de Nanchititla, established in 2004-2006 (lat 18.8654, long -100.4158, $1750 \mathrm{~m}$; Figure 1) within the mountain complex of the same name in the southwestern part of Estado de México, and $250 \mathrm{~km} \mathrm{SSW}$ of the Querétaro site. It harbors oak-pine forest, and is just above the upper limit of deciduous tropical forest.

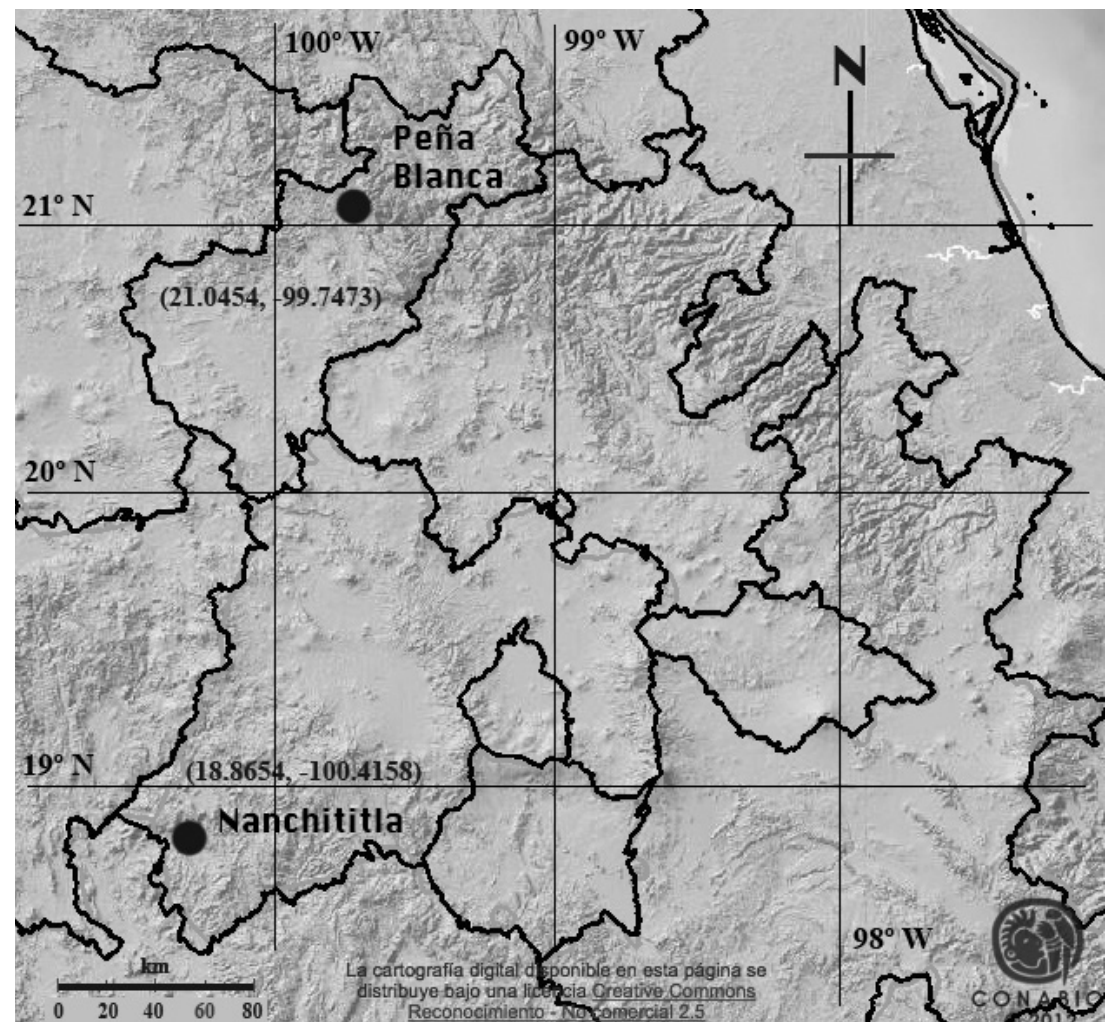

Figure 1. Geographic location of two study sites of Central Mexico. In Peña Blanca, Querétaro, the information on food was taken by Macrotus waterhousii. Base map taken from CONABIO (2012) 
Insect materials and analyses. Food remains left by a group of $M$. w. bulleri were collected under their roost at the twilight zone of the abandoned mine. The site was visited on July 7th, 1983; at that time it was occupied by ca. 40 M. w. bulleri, and five were captured as vouchers and deposited in the National Collection of Mammals at the Instituto de Biología, UNAM (CNMA 20013, 20014 and 20017, females; and 20015 and 20016, males).

The sample of insect remains in Nanchititla was collected by Ó. Sánchez on April 4,1989 , from a refuge of M. w. mexicanus below a tile roof. Only three bats were seen at the time of collection of the sample, but the amount of insect remains suggested either a larger group or persistent utilization of the roost.

We carefully picked up all insect remains. The exoskeletal (mostly wings and legs) materials were placed and transported in cotton-cushioned boxes, so that further fragmentation was avoided. These materials were separated in the laboratory, identified to orders and families and, with the help of expert entomologists from the Instituto de Biología, Universidad Nacional Autónoma de Mexico, to genus and species whenever possible. These insect remains were left in the respective laboratories.

Assuming that all or most insects captured by the bats were directly consumed above the site where the remains were accumulated, we estimated the numbers of individual insects of each taxon in the sample on the basis of the number of paired appendages and/or heads present. The proportional occurrence of these taxa in the sample was studied at two taxonomic levels, order and family, calculating percentages to facilitate comparisons. Genus and species were considered for other analyses, pertaining to size and ecological relations.

Size of the most abundant prey taxa in our sample was assessed with the aid of published measurements for the particular species; wingspan dimensions of the most frequent prey taxa were obtained from the Bug Guide Group, hosted at lowa State University (2014). With these data frequency and size relationships were studied.

Insect orders found in the sample were ranked following the invertebrate general body hardness scale devised by Freeman (1981); numbers correspond to scores, in ascending order of hardness: 1) Ephemeroptera, Isoptera, Trichoptera, Plecoptera, Neuroptera, Mecoptera, and Diptera; 2) Araneida, Odonata, Homoptera and Lepidoptera; 3) Orthoptera and Scorpionida; 4) Hemiptera, Hymenoptera, Chilopoda, Diplopoda and large Aeschnoidea; and 5) Coleoptera. The corresponding scores were weighted with the estimated frequencies as done by that author, thus obtaining the final prey hardness indicator.

In order to assess the composition of the sample with regard to energy content of prey taken by $M$. waterhousii, a general indirect index of energy reward was devised. Assuming that large body size of prey implies more energy reward for a predator, a size indicator (wingspan) of a given insect prey species was multiplied by its estimated frequency in the sample, and the result was taken as a general indicator of energy input and labeled as Energy Reward Indicator; ERI. The ERI was calculated for the eight most frequent insect taxa ( $>20$ individuals) that were effectively determined to species in the sample, except for one noctuid moth which ranked sixth in frequency with $n=26$, but could not be positively determined to species, which prevented proper wingspan allocation. Log ERI was regressed against log raw frequency; data were processed with PAST3 software (Hammer 2015).

In relation to the comparison with a food sample from a more mesic environment, we relied on the insect identifications published by Barboza-Eguiluz and Bernal- 
Jiménez (1992), on the basis of a food sample of M. waterhousii from Nanchititla, State of Mexico. Insect prey data from Peña Blanca (an arid region) were compared with those of Nanchititla (oak-pine forest, just above tropical deciduous forest), at the same level of identification (i. e. families), and a general comparison of overall insect diversity was done with Shannon-Wiener's $H^{\prime}$ estimate $\left(H^{\prime}=-\Sigma p_{i} \ln p_{i}\right)$, calculating the evenness value as $\mathrm{H}^{\prime} / \mathrm{H}_{\max }=\mathrm{H}^{\prime} /$ In S (Magurran and McGill 2011).

A brief revision of published ecological relationships of main insect prey species present in the sample from Peña Blanca, Querétaro, including human interests such as agriculture, was also performed.

\section{Results}

Taxonomic composition and proportions of prey in the sample from Peña Blanca. Food remains discarded by M. w. bulleri at Peña Blanca were estimated to represent 661 individual insects (mostly wings and legs). No other arthropods were found, neither fruit pulp nor seeds were observed among the food remains or directly attached to the voucher specimens; insect species and genera arranged by orders and families are shown in Table 1. At the ordinal level, the greatest percentage of items consumed by M. w. bulleri (341 out of $661 ; 51.59 \%$ ) is represented by Lepidoptera (within this order the families Erebidae, Saturnidae, and Sphingidae were most prevalent, followed by Noctuidae; together, the four moth families represent $49.47 \%$ of the total sample). The Order Hymenoptera follows, represented by an estimated 192 individuals (29.05 $\%$ ), notably all from a single species of the family Formicidae (the winged stage of the ant Atta mexicana). Although more modestly, the Orders Coleoptera $(8.47 \%$, mainly Scarabaeidae), Orthoptera (6.51\%, mainly Acrididae and Tettigoniidae), and Neuroptera (3.33 \%) were also present. Proportions of Odonata, Homoptera and Isoptera were all low (under $1 \%$; Table 1; Figure 2). Determinations provided at the family, genus and species levels, helped us study the frequencies of some particular

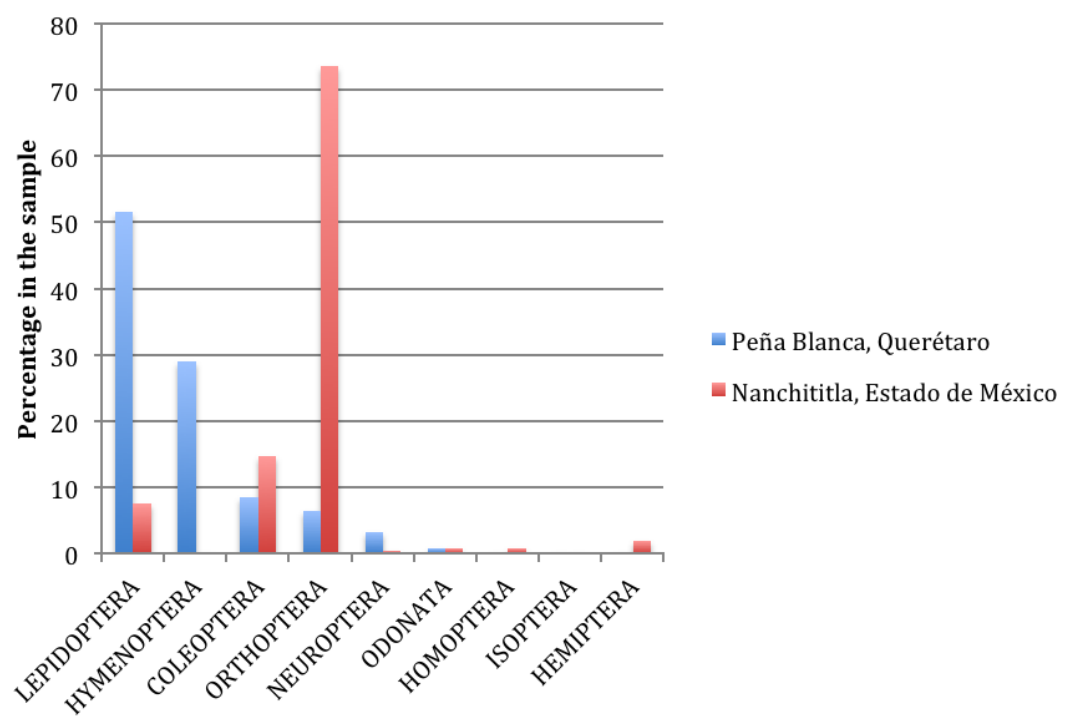

Figure 2. Order level composition of two food samples from M. waterhousii. Data for Querétaro are from Table 1. The list for Nanchititla, Estado de México (Barboza-Eguiluz and Bernal-Jiménez 1992), at the order level (and family) indicates percentages as follows: Orthoptera (73.63\% of the total sample: Acrididae $50 \%$, Tettigoniidae $17.01 \%$ and Gryllidae $6.62 \%$ ); Coleoptera, Cerambycidae (14.70 \%); Lepidoptera (7.56 \% of the sample: Noctuidae $5.04 \%$, Geometridae $0.84 \%$, Arctiidae $0.84 \%)$ and Pyralidae $0.84 \%)$; Hemiptera, Coreidae (2.01\%); Odonata: $(0.84 \%)$; Homoptera (0.84 \%); and Neuroptera $(0.42 \%)$ 
taxa in the food sample left by M. w. bulleri in the Peña Blanca site (Figure 3).

Although as mentioned above, lepidopterans of several different families represented the bulk of consumed prey (both in number and mass considering the size of several moths; see the section on size, below), as a single species the winged form of the "arriera" ant (Atta mexicana) was the most frequent specific taxon at $29.05 \%$ of the total sample. Among erebid moths, Melipotis indomita was highest in frequency (14.37\%); the saturnid moth, Sphingicampa hubbardi followed closely with (12.86\%); and among sphingids, Callionima parce accounted for10.44 \%. Scarabaeid beetles, Phyllophaga cf. ravida, comprised $5.60 \%$. Among noctuid moths an undetermined genus followed with $3.93 \%$, and the species Helicoverpa (Heliothis) zea with $3.03 \%$. Antlions (Neuroptera: Myrmeleontidae cf. Brachynemurus) were represented by an estimated $3.03 \%$. We also recovered remains of acridid grasshoppers, Trimerotropis cf. pallidipennis (1.66 \%). In all, the particular taxa mentioned above account for 554 individuals (83.97\%) of the sample we analyzed.

Atta mexicana, most lepidopterans, Neuroptera, and Isoptera found in Peña Blanca are crepuscular or nocturnally flying species that constitute $84.09 \%$ of food items identified, and only $19.4 \%$ of insects identified are known to be truly diurnal fliers such as anisopteran odonates; among the latter there was an unidentified species of the genus Anax (family Aeshnidae), and other of Tramea (family Libellulidae).

Size distribution of prey in the Peña Blanca sample. Size of the eight most frequent prey species in the sample (see taxa in Table 1) varies in known wingspan between 25 and $80 \mathrm{~mm}$. Based on these published measurements the analysis of average wingspan for these eight taxa revealed that most frequent prey were $51 \pm 14.01 \mathrm{~mm}$ in width. The smallest taxon among prey found in the sample was Helicoverpa zea, with a known average wingspan of $38.5 \mathrm{~mm}$. Figure 4 summarizes these results. The wingspan range as published (Bug Guide Group 2014) for the eight most frequent prey species was ample, but the two most frequent species in the sample (the winged form of the ant

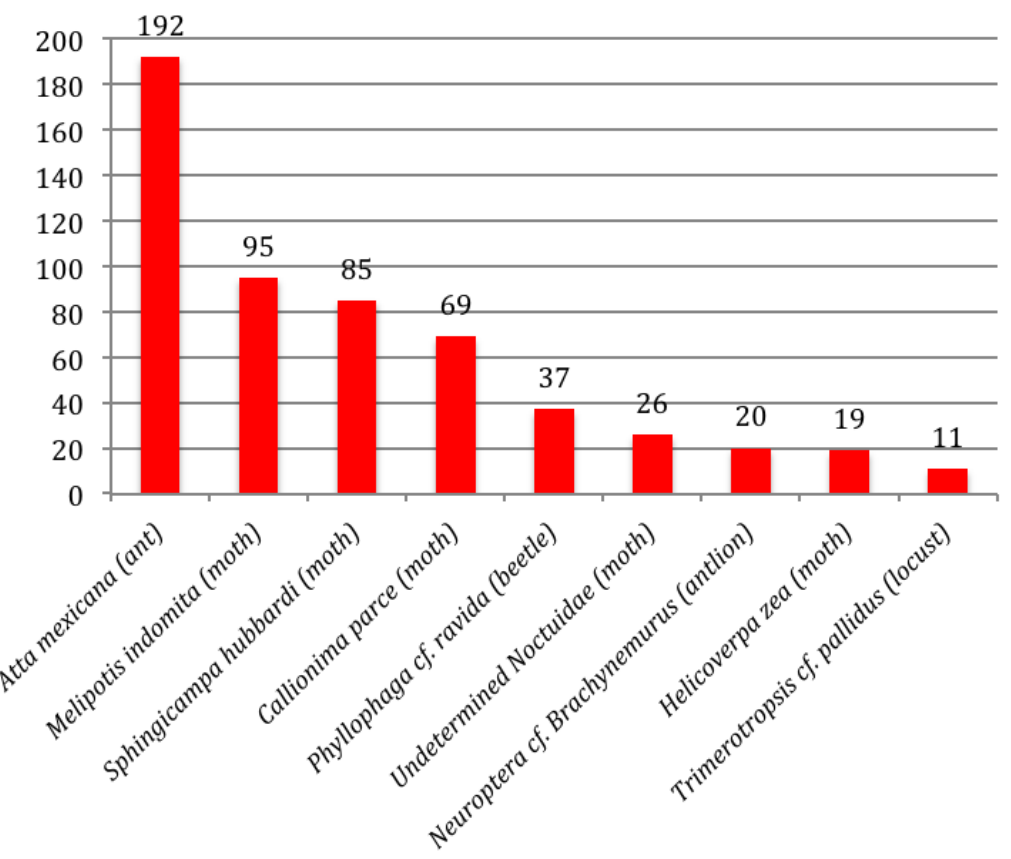

Figure 3. Estimated number of individuals of most frequent insect taxa identified in the food sample of $M$. waterhousii from Querétaro. Percentages are mentioned in the text. 
Atta mexicana and the moth Melipotis indomita, together accounting for $43.42 \%$ of the sample) have a known average wingspan of slightly less than $45 \mathrm{~mm}$. Four other relatively frequent prey species in the sample, the white-grub imagos (Phyllophaga cf. ravida), an antlion (cf. Brachynemurus), another moth (Helicoverpa zea), and a locust (Trimerotropis cf. pallidipennis), ranged from 37.5 to $52.5 \mathrm{~mm}$ in wingspan. It was surprising that the largest moths, Sphingicampa hubbardi and Callionima parce, with average wingspans of 71.5 and $73.5 \mathrm{~mm}$ respectively, represented $23.3 \%$ of the sample.

Average relative hardness of consumed prey. Considering that $M$. waterhousii is similar to M. californicus in overall size, and also in jaw and dental structure, the average hardness (AH) score for consumed prey in our samples at the Order level (sensu Freeman (1981)) was expected to be similar to the 3.3 average score reported in that work for the most important prey for M. californicus (mostly $>10 \%$ of the total sample reported by Ross in 1967). With the same treatment for the sample for $M$. waterhousii from Peña Blanca, our results were $\mathrm{AH}=3.6$ (Lepidoptera, Hymenoptera, and Coleoptera), and $\mathrm{AH}=3.3$ (Orthoptera, Coleoptera, and Lepidoptera) for that from Nanchititla.

Estimation of energy reward from prey in the sample. In a linear regression of the logarithm of prey frequency against the logarithm of the Energetic Reward Index (ERI) of the insect species in the sample, two intermediately frequent -and largemoths (Sphingicampa hubbardi and Callionima parce) fall outside and above the $95 \%$ confidence interval. This may indicate that these more energetically rewarding prey species were deliberately pursued by this bat, despite the greater effort required for their capture. All other prey fall within the confidence interval, including the more frequent but much smaller moth Melipotis indomita and the also small and seasonally abundant Atta mexicana (Figure 5).

Comparison with data from the subtropical site. The overall composition at the ordinal level of the samples from Peña Blanca, Querétaro (this work) and Nanchititla,

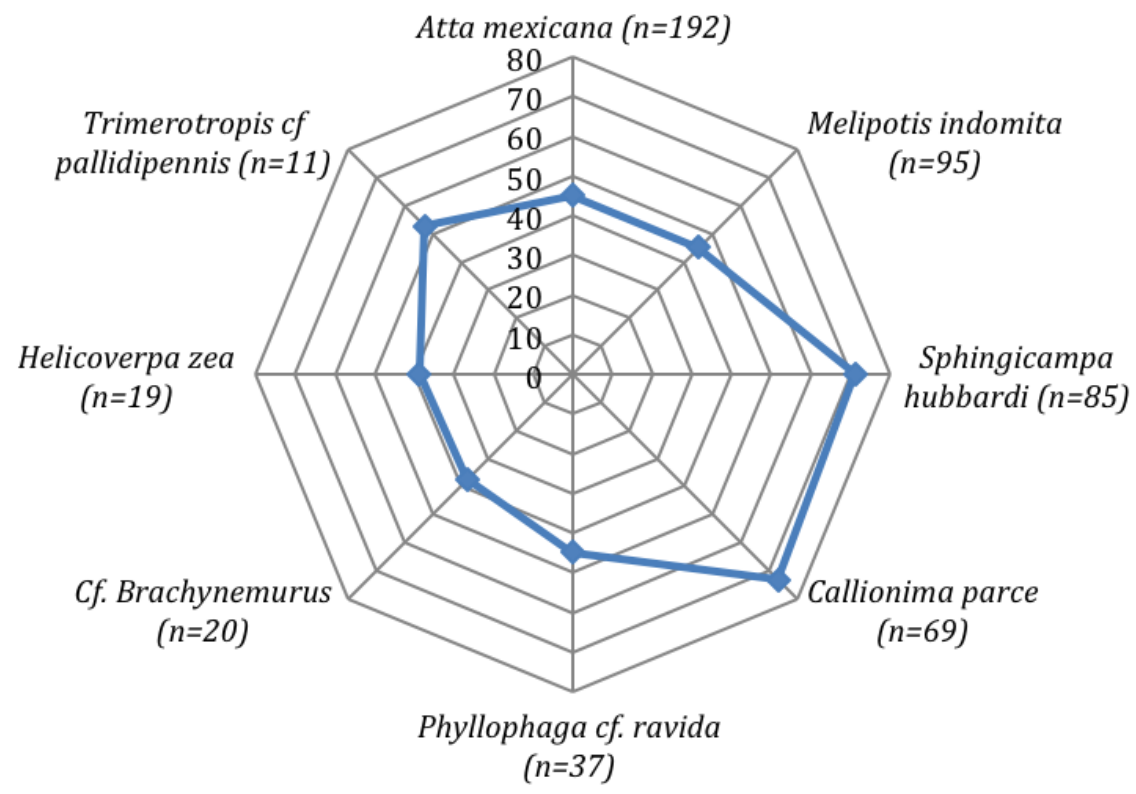

Figure 4. Average known wingspan for eight of the most frequent taxa of insects found in the sample of food remains discarded by Macrotus waterhousii collected in Peña Blanca, Querétaro, according to published sources (Bug Guide Group 2014). Insect taxa are ordered clockwise, according to decreasing abundance in the sample; measurements are in millimeters (an unidentified noctuid moth was excluded since its specific wingspan can not be determined). 
Table 1. Composition of the sample of insect food remains left by Macrotus waterhousii bulleri in a roost in Peña Blanca, Querétaro. The minimum number of individuals, estimated on the basis of fragments found, is shown. Subtotals by groups are shown in parentheses. *Some authors have included Mantidae in the Order Mantodea, and Blattidae in Blattodea.

\begin{tabular}{|c|c|c|c|c|}
\hline Order & Family & Genus & Species & $\begin{array}{l}\text { Individuals } \\
\text { estimated }\end{array}$ \\
\hline \multirow[t]{21}{*}{ Lepidoptera (341) } & \multirow[t]{2}{*}{ Erebidae (97) } & Melipotis & indomita & 95 \\
\hline & & Catocala & sp. & 2 \\
\hline & \multirow[t]{2}{*}{ Saturnidae (92) } & Sphingicampa & hubbardi & 85 \\
\hline & & Automeris & sp. & 7 \\
\hline & \multirow[t]{10}{*}{ Sphingidae(90) } & Callionima & parce & 69 \\
\hline & & Callionima & sp. & 7 \\
\hline & & Erinnyis & alope & 5 \\
\hline & & Erinnyis & ello & 2 \\
\hline & & Xylophanes & pluto & 2 \\
\hline & & Sphinx & sp. & 1 \\
\hline & & Smerinthus & saliceti & 1 \\
\hline & & Erinnyis & obscura & 1 \\
\hline & & Adhemarius & sp. & 1 \\
\hline & & Agrius & cingulatus & 1 \\
\hline & \multirow[t]{4}{*}{ Noctuidae (48) } & Gen. & sp. & 26 \\
\hline & & Helicoverpa (Heliothis) & zea & 19 \\
\hline & & Mythimna & unipuncta & 2 \\
\hline & & Lycophotia & sp. & 1 \\
\hline & Bombycidae (10) & Apatelodes & sp. & 10 \\
\hline & undetermined (3) & Gen. & sp. & 3 \\
\hline & Crambidae (1) & Megastes & praxiteles & 1 \\
\hline Hymenoptera (192) & Formicidae (192) & Atta & mexicana & 192 \\
\hline \multirow[t]{7}{*}{ Coleoptera (56) } & \multirow[t]{5}{*}{ Scarabaeidae (48) } & Phyllophaga & cf. ravida & 37 \\
\hline & & Gen. & sp. & 4 \\
\hline & & Phanaeus & sp. & 3 \\
\hline & & Diplotaxis & sp. & 2 \\
\hline & & Pelidnota & sp. & 2 \\
\hline & Elateridae (6) & Gen. & sp. & 6 \\
\hline & Cerambycidae (2) & Gen. & sp. & 2 \\
\hline \multirow{14}{*}{ Orthoptera (43) } & \multirow{6}{*}{ Acrididae (25) } & Trimerotropis & cf. pallidipennis & 11 \\
\hline & & Gen. & sp. & 4 \\
\hline & & Gen. & sp. & 4 \\
\hline & & Schistocerca & sp. & 3 \\
\hline & & Heliastus & sp. & 2 \\
\hline & & Arphia & sp. & 1 \\
\hline & \multirow[t]{5}{*}{ Tettigoniidae (14) } & Amblycorypha & sp. & 5 \\
\hline & & Gen. & sp. & 5 \\
\hline & & Neoconocephalus & sp. & 2 \\
\hline & & Chloroscirtus & sp. & 1 \\
\hline & & Microcentrum & sp. & 1 \\
\hline & *Mantidae (2) & Stagmomantis & sp. & 2 \\
\hline & \multirow[t]{2}{*}{ *Blattidae (2) } & Gen. & sp. & 1 \\
\hline & & Gen. & sp. & 1 \\
\hline \multirow[t]{2}{*}{ Neuroptera (22) } & Myrmeleontidae (20) & cf. Brachynemurus & sp. & 20 \\
\hline & Ascalaphidae (2) & Gen. & sp. & 2 \\
\hline \multirow[t]{4}{*}{ Odonata (5) } & Aeshnidae (2) & Anax & sp. & 2 \\
\hline & Gomphidae (1) & Erpetogomphus & sp. & 1 \\
\hline & \multirow[t]{2}{*}{ Libellulidae (2) } & Paltothemis & sp. & 1 \\
\hline & & Tramea & sp. & 1 \\
\hline Homoptera (1) & \multirow{3}{*}{$\begin{array}{l}\text { Cicadidae (1) } \\
\text { undetermined (1) }\end{array}$} & Gen. & sp. & 1 \\
\hline \multirow[t]{2}{*}{ Isoptera (1) } & & Gen. & sp. & 1 \\
\hline & & & Total & 661 \\
\hline
\end{tabular}




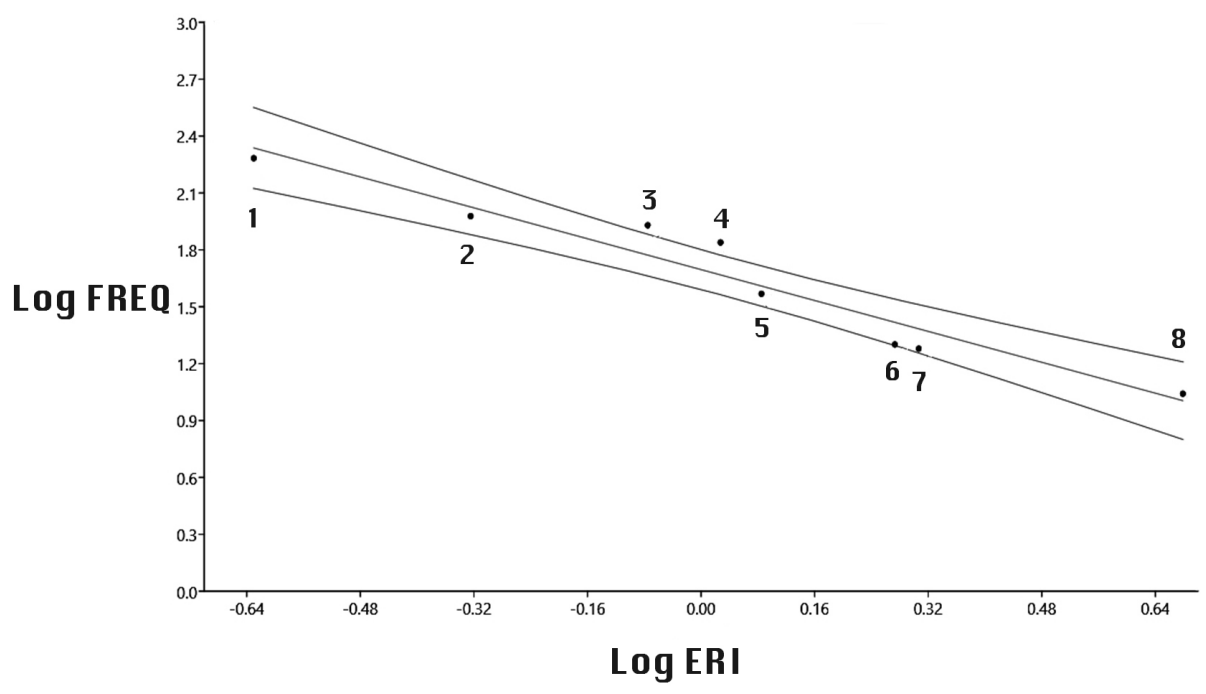

Figure 5. Wingspan of a given insect prey species multiplied by its frequency within the sample, of food remains left by Macrotus waterhousii bulleri in Querétaro, was taken as a general indicator of energy input (Energy Reward Indicator, ERI), and was calculated for eight most abundant insect prey species in the sample; then the log-transformed frequencies were regressed against log ERI $\left(r^{2}=0.93101\right.$, confidence interval $\left.=0.95\right)$. Insect taxon codes in the graph are: 1, Atta mexicana; 2 , Melipotis indomita; 3, Sphingicampa hubbardi; 4, Callionima parce; 5, Phyllophaga cf. ravida; 6, Cf. Brachynemurus; 7, Helicoverpa (Heliotis) zea; and 8, Trimerotropis cf. pallidipennis. S. hubbardi y C. parce were more frequent than statistically expected.

Estado de México (Barboza-Eguiluz and Bernal-Jiménez (1992)) reveals noticeable differences in the percentages (Figure 2). Among orthopterans, acridids represented half of consumed insects at Nanchititla followed by tettigoniids and gryllids. Longhorned beetles (Cerambycidae) made up $14.7 \%$ and noctuid moths only $5.04 \%$. Together, these insect groups explain $93.3 \%$ of the total in that sample.

The high importance of lepidopterans in the sample from Peña Blanca $(51.58 \%)$ contrasts with their low profile in that from Nanchititla (7.56\%). On the other hand, orthopterans were plentiful in the sample from Nanchititla (74.66 \%), while they were not so abundant in Peña Blanca (6.50\%). Hymenopterans were the second most important group in Peña Blanca (29\%) but were absent in the sample from Nanchititla.

With the caveat we expressed before about comparisons, we found significant differences in proportions of Lepidoptera, Coleoptera and Orthoptera; i.e. those orders with more individuals in the samples $\left(X^{2}=240.70, g . I=2, n=555, P=0.001\right)$. If all orders in both samples were considered, the difference would become even greater since some orders are present in one sample and not in the other, and viceversa.

A coarse assessment of the diversity of insect orders present in each food sample yielded Shannon-Wiener's H' values as follows: Peña Blanca 1.225, and Nanchititla 0.883. Evenness yielded: Peña Blanca 0.591, and Nanchititla 0.454. Maximum diversity $\left(\mathrm{H}_{\text {max }}\right)$ : Peña Blanca 2.079, Nanchititla 1.945. Hence, diversity of insect orders was slightly greater in the sample from Peña Blanca, as was evenness in proportions of individuals.

Known ecological relationships of insect prey determined in the sample. The detailed revision of pertinent literature on the most important components of the food sample of $M$. waterhousii from Peña Blanca brought the following facts to attention: colonies of the ant, Atta mexicana are an important factor in the foliar dynamics of xeric plant communities, especially for plants such as Larrea tridentata and Cercidium spp. (Smith 1963; Mintzer 1979); nuptial flights of Atta occur during only a few days, 
usually coinciding with the first heavy rains (Acuña et al. 2011). The life cycle of the moth Melipotis indomita is intimately related to several species of mesquite plants (Prosopis spp.), so much that it has been proposed as a potential biocontrol agent for mesquite invasions (Deloach and Cuda 1994). The life cycle of the saturnid moth Sphingicampa hubbardi is linked also with mesquite, with Acacia spp., and with the "palo verde" (Cercidium spp.); adult moths emerge at dusk, only during a few weeks (eventually months) after the first heavy rains (Tuskes et al. 1996). Other sphingids, like Callionima parce, are known to fly between April and September in the southern USA, and northern and central Mexico, although little information is available on its natural history (Brown and Donohue 1989). The moth larvae of the corn earworm or maize worm Helicoverpa (Heliothis) zea are known to attack corn, tomatoes, sweet peppers, cabbage, and lettuce (Flint 1985); local and regional dispersion of this moth species is known to depend on swift, low-altitude air currents, especially those associated with night thermal inversions (Beerwinkle et al. 1994). The coleopterans more frequently found in the sample from Peña Blanca (Phyllophaga cf. ravida) are also of agricultural importance, both as larvae and as adults; they attack potatoes, and even some wild plants with starch-rich tubercular roots. After nearly two years growing as voracious larvae, adults emerge after the onset of the rainy season (MayJune in Mexico) and frequently climb shrubs (Woodruff and Beck 1989). Locusts of the genus Trimerotropsis, moderately present in the remains recovered from Peña Blanca, may damage crops (corn, barley, and even cotton), especially during their

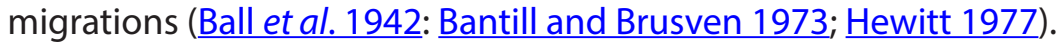

\section{Discussion}

The high frequency of the order Lepidoptera in Peña Blanca coincides with the findings of Emrich et al. (2013) for Jamaica. Several noctuid moths (some now placed in the family Erebidae) are well known for their habit of ceasing wingbeat during flight in response to the presence of foraging insectivorous bats (Hoy 1992); despite this defensive trait, representatives of this family are abundant in our sample from Peña Blanca which might indicate at least partial ineffectiveness of that behavioral resource.

In addition, in the arid environment of Peña Blanca, Querétaro, the consumption of insect species of clearly restricted seasonal availability (such as winged individuals of the leaf-cutting ant Atta mexicana, and Phyllophaga beetles) was conspicuous. The high number of individuals of the ant Atta mexicana in our sample appears to indicate apparently opportunistic feeding of $M$. waterhousii, because of the known timelimited and abundant presence of the winged forms of this leaf-cutting ant during summer (Acuña et al. 2011).

The only species of Hymenoptera (Atta mexicana), all Lepidoptera, eighteen Orthoptera, plus all Neuroptera and Isoptera were adult insects, known to be crepuscular or nocturnal and they might have been captured while in flight; together, these constitute $86.84 \%$ of the individuals estimated on the basis of food items found. Less than one fifth of insects were identified as diurnal fliers; these would seem to complement the local food mainstays and may have been taken at night from twigs, or even from the ground while perching (Williams 1935).

Various small insect taxa constitute the bulk of captures in the sample, but the unexpected high percentage of large moths may indicate that Macrotus waterhousii is 
also able to pursue and capture larger prey if available. As mentioned, in Peña Blanca the relatively small erebid moth Melipotis indomita was the most abundant moth in our sample; but the much larger saturnid Sphingicampa hubbardi was also taken. Macrotus waterhousii might derive advantage of temporary favorable circumstances in terms of the availability of more energy rewarding food, with lesser regard for size and ease of capture; this is supported by the higher than expected presence of large sphingids like Callionima parce in the sample.

As expected from the similarity in form and overall size of $M$. waterhousii and M. californicus (particularly their intermediately robust masticatory jaw structure) the prediction of intermediate prey hardness for $M$. waterhousii derived from the hypothesis put forward by Freeman (1981) was supported, pointing toward similar niches for both species in this respect. On the other hand, overwhelming dominance of insects in earlier diet reports for M. waterhousii (absolute in the present analysis), and scarce records of fruit as food in the literature are both consistent with the concepts of Schondube et al. (2001) relative to kidney structure and Trehalase activity, indicating basic insectivory of these bats. One possibility is that records of fruit as food of $M$. waterhousii could indicate an eventual need for complementary nutrients.

Diurnal flying insects like Anax sp. and Tramea sp. (Odonata) were scarce in the Querétaro sample; however, there is a record of $M$. w. jamaicensis consuming significant amounts of Anax junius in Jamaica, and of $M$. w. minor preying upon several libellulids including Tramea sp. in Grand Cayman (Dunkle and Bellwood (1982)). We agree with these authors in that these food items may be taken opportunistically; these insects would be available in flight for foraging bats for a very short time daily during the crepuscule, thus they might have been captured while perching at night, and perhaps high local abundance may be a factor in the Jamaica case. There is recent evidence of low intensity, frequency modulated echolocation for $M$. waterhousii (Murray et al. 2009); thus, the potential ability of this bat for performing repetitive three-dimensional echolocation approaches can be an important feature for recognition of night-perching prey in total darkness.

Larger prey could be favored in terms of greater energetic compensation for the predator, but then a combination of search, pursuit, and subduing costs (Griffiths 1980) may exert counterbalance; on the other hand, prey availability and behavior would also tend to compensate. Macrotus waterhousii seems to respond to energetic compromises; local (and seasonal) differential availability of prey species might determine its food intake, with a predominant consumption of more abundant (and moderate-sized) insects, but as this bat is capable of effectively preying on large insects such as the moths $S$. hubbardi and C. parce, it might spend additional effort pursuing the higher energetic reward these insects provide, if they are present. Differential prey availability, in space and time, might exert an important modulation and influence on the final result of its local food intake.

In comparing sample composition from Peña Blanca and Nanchititla we are aware that both places have radically different vegetation. Peña Blanca has xerophyllic scrub related to the Chihuahuan Desert (Zamudio 1984), and Nanchititla mostly oakpine forest above subtropical deciduous forest (Aguilar-Ortigoza 1994) allied to the Transvolcanic Belt and the Balsas Basin; in consequence, the entomofauna would be expected to be different. Lepidopterans were most important in Peña Blanca, while in Nanchititla they ranked third. 
Conversely, orthopterans were the most abundant group in the sample from Nanchititla, while they only ranked fourth in Peña Blanca. Besides differences in insect faunal composition of both areas, exposure of insects to foraging bats might also be different in both environments, primarily in terms of vegetation complexity and density. For example, it is unclear why the sample from Nanchititla bears a very low proportion of lepidopterans (only $5.04 \%$; including Noctuidae and even smaller quantities of Geometridae, Arctiidae, and Pyralidae) as these insects were easily seen at night in that area when the sample was found (Ó. Sánchez, pers. obs.1989). The high presence of orthopteran remains in Nanchititla (Acrididae, Tettigonidae, and Gryllidae) might reflect a relative ease of capture of night-perching insects, which become more vulnerable while walking on exposed tree trunks within an otherwise complex environment. Cerambycid beetles were also present as food remains in the sample from Nanchititla and Ó. Sánchez (pers. obs. 1989) saw these beetles there during that rainy season, emerging at night and walking on the bark of trees.

The present results for $M$. waterhousii would seem to partially support the opinion of Segura-Trujillo et al. (2016) about a trend for Nearctic bats to feed mainly on weak-flying and weakly sclerotized arthropods (e. $g$. Lepidoptera were prevalent in Peña Blanca) whereas in tropical America that might be different (e. g. Orthoptera dominated in the Nanchititla sample). However, the differences here reported belong to one and the same bat species, present both in Nearctic and Neotropical ecosystems, which presumably bear different entomofaunal composition. As we are dealing with different bat subspecies (M. w. bulleri in Peña Blanca, and M. w. mexicanus in Nanchititla) it might also be argued that differences in sample composition might be due to differences in food preferences of these two bat subspecies. However, a more parsimonious explanation of differences in sample composition may simply involve differences in the taxonomic composition of local insect faunas. To advance in bat feeding guild study it seems advisable to explore local insect faunal composition and abundance patterns, in addition to prey flight abilities and exoskeleton hardness, because the idea that weak-flying and weakly sclerotized arthropods in tropical America are found only in low numbers (Segura-Trujillo et al. 2016) might seem questionable.

Comparisons of food items ingested by $M$. waterhousii in both localities, based on presence-absence of major arthropod taxa (i. e. orders) are valuable but limited; in the present case, had we only considered presence or absence of orders it may have seemed that $M$. waterhousii feeds on similar insects in both localities, because the samples from Peña Blanca and Nanchititla share $66.6 \%$ of insect Orders. However, if one compares at least families and their relative abundance in the samples, more subtle differences and patterns can be perceived; this makes it desirable to work on bat diets at least at the family level.

As we are dealing with different bat subspecies (M. w. bulleri in Peña Blanca, and $M$. w. mexicanus in Nanchititla) it might be argued that differences in sample composition might be due to differences in food preferences of these two bat subspecies. However, a more parsimonious explanation of differences in sample composition may simply involve differences in the taxonomic composition of local insect faunas.

A single hymenopteran species ranked high in Peña Blanca while no hymenopterans were found in the remains from Nanchititla. This fact points towards local alimentary opportunism linked to prey availability by $M$. waterhousii since that particular hymenopteran was the nuptial winged form of Atta mexicana, known to fly 
in abundant swarms only for a few days during the summer rainy season (Acuña et al. 2011). In any case, that purported opportunism is perhaps modulated by energy reward, size, exposure, and effort needed for capture, as explained above. As $M$. waterhousii is also capable of occasionally preying on large insects, our combined results seem to indicate versatility of this bat as a predator.

Leaving aside the seasonal high intake of winged leaf-cutting ants of only one species in our sample, certain moth species are, together, the most important component in the sample from Peña Blanca. Some of these are recognized as agricultural pests, for example the corn earworm or maize worm Helicoverpa (Heliothis) zea is known to attack corn, tomatoes, sweet peppers, cabbage, and lettuce (Flint 1985); this moth species is also known to be of importance for other insectivorous bats, such as Tadarida brasiliensis mexicana (Molossidae), a species that has been documented following large moving populations of Helicoverpa zea (McCracken 1996).

The coleopterans more frequently found in the sample from Peña Blanca (Phyllophaga cf. ravida) are also of agricultural importance (Woodruff and Beck 1989). Despite these suggestive facts; however, M. waterhousii does not form large colonies in the thousands or millions, but lives in sparse, much smaller aggregations up to 500 individuals (Anderson 1969); thus its predatory impact on regional populations of these insects, although noticeable, may be limited in its demographic effects.

We must admit that data on food composition for M. waterhousii are still far from satisfactory. Although the present sample seems to be the most completely studied to date, it is not representative of the ample geographic range of this bat and the different vegetation types it inhabits. No full generalization is thus warranted, but observations derived from this study may elicit interest in performing deeper studies of the feeding ecology of this bat. This would add information on bat diets, which has been considered by Segura-Trujillo et al. (2016) a critically important component of any useful future guild classification.

\section{Conclusions}

a) In the sample studied from arid Querétaro, Macrotus waterhousii bulleri appears to prey opportunistically on an ample variety of insects of different taxonomic groups and habits, possibly according to seasonal abundance. Moths were predominant as a group, but as a single species, the arriera ant (Atta mexicana, its reproducing winged form known to fly only during a few days during the summer) was most frequent in this sample. Nocturnal insects were prevalent, while diurnal fliers were scarce and may have been captured while perching at night.

b) Macrotus w. bulleri seems to be able to capture insects at least in the range of $25-80 \mathrm{~mm}$ in wingspan; average in the sample was about $51 \mathrm{~mm}$, but this bat can prey on large moths with a wingspan of more than $70 \mathrm{~mm}$ if available.

c) The prediction of intermediate insect prey hardness at the order level derivable for $M$. waterhousii from Freeman's (1981) hypothesis and scale of measurement proved tenable, indicating that this bat may prefer insects of intermediate body hardness.

d) In terms of energetic reward, according to the sample contents although large moths were more abundant than statistically expected, there is not convincing evidence that large prey might be favored. This is probably because of a combination of prey availability, seasonality and behavior, plus search, pursuit, and subduing costs, which may exert counterbalance.

e) Local insect faunas and habitat structure may be major factors determining variations in feeding composition and feeding strategies of $M$. waterhousii as indicated by comparison of two 
food samples, one from an arid and other from a subtropical site.

f) Although in fact $M$. waterhousii feeds on some insect species of ecological and economic importance, the impact of its predatory activities may be limited since known colonies of this bat are not large and their stability is not known.

g) Food samples from more and diverse areas within the distribution of the species, and of different seasons within a particular site, need to be obtained and studied to test hypotheses here proposed. Food sample study at the family, or more detailed taxonomic levels, is recommended.

\section{Acknowledgements}

We are greatly indebted to W. López-Forment for his invaluable help in the laboratory, as well as to expert entomologists at Instituto de Biología, Universidad Nacional Autónoma de Mexico (UNAM): C. R. Beutelspacher, E. González-Soriano, J. Bueno-Soria, S. Zaragoza-Caballero, E. BarreraVargas, and E. Mariño-Pedraza, who most generously contributed their knowledge and help for the determination of insect taxa. OS acknowledges support from the Instituto de Biología, UNAM, during his tenure there. Thanks are also due to Ulises Aguilera and his former students C. Barboza-Eguiluz and A. Bernal-Jiménez, from the Facultad de Ciencias, Universidad Autónoma del Estado de México, for their help during the field trip to Nanchititla when the comparative sample was collected; and U. Aguilera graciously handed us the published report. We also appreciate field assistance provided by J. Galván during collection of the Querétaro sample. Last, but not least, we thank the editors and three anonymous referees, who painstakingly reviewed our initial manuscript greatly improving its structure and clarity.

\section{Literature cited}

Acuña, A. M., L. Caso, M. M. Aliphat, and C. H. Vergara. 2011. Edible insects as part of the traditional food system of the Popoloca town of Los Reyes Metzontla, Mexico. Journal of Ethnobiology 31:150-169.

Aguilar-Ortigoza, C. A. 1994. La vegetación de la zona núcleo del parque Sierra de Nanchititla. Revista de la Escuela de Ciencias de la Universidad Autónoma del Estado de México 4:6-16.

Anderson, S. 1969. Macrotus waterhousii. Mammalian Species 1:1-4.

Ball, E. D., E. R. Tinkham, R. Flock, and C. T. Vorhies. 1942. The grasshoppers and other Orthoptera of Arizona. Arizona Agricultural Experimental Station, Technical Bulletin 93:255-373.

Bantill, J. C., And M. A. Brusven. 1973. Food habits and ecology of grasshoppers in the Seven Devils Mountains and Salmon River Breaks of Idaho. Melanderia 12:1-21.

Barboza-Eguiluz, C., and A. Bernal-Jiménez. 1992. Estudio preliminar de la dieta de Macrotus waterhousii en la Reserva Ecológica de Nanchititla, Tejupilco, Estado de México. Resúmenes del 3er. Encuentro regional de Flora y Fauna de la Región Centro-Sur de México. Cuernavaca, Morelos.

Beerwinkle, K. R., J. D. López, J. A. Witz, P. G. Schleider, R. S. Eyster, and P. D. Lingren. 1994. Seasonal radar and meteorological observations associated with nocturnal insect flight at altitudes to $900 \mathrm{~m}$. Environmental Entomology 223:676-683.

BeLL, G. P. 1985. The sensory basis of prey location by the California leaf-nosed bat Macrotus californicus (Chiroptera: Phyllostomidae). Behavioral Ecology and Sociobiology 16:343-347.

Bell, G. P., G. A. Bartholomew, and K. A. Nagy. 1986. The roles of energetics, water economy, foraging behavior, and geothermal refugia in the distribution of the bat, Macrotus californicus. Journal of Comparative Physiology, B 156:441-450.

Bell, G. P., And M. B. Fenton. 1986. Visual acuity, sensitivity and binocularity in a gleaning insectivorous bat, Macrotus californicus (Chiroptera: Phyllostomidae). Animal Behavior 34:409-414.

Bug Guide Group. 2014. Identification, Images, \& Information For Insects, Spiders \& Their Kin For the United States \& Canada. Hosted by the lowa State University. http://bugguide.net/node/view/15740. 
Consulted: January 20, 2015.

Brown, J. W., AND J. P. Donohue. 1989. The Sphingidae (Lepidoptera) of Baja California, Mexico. Journal of the Lepidopterists' Society 43:184-209.

CONABIO. 2012. Portal de Geoinformación. Sistema Nacional de Información sobre Biodiversidad. Comisión Nacional para el Conocimiento y Uso de la Biodiversidad. http://www.conabio.gob.mx/ informacion/gis/. Consulted: January 26, 2016.

Deloach, C. J., AND J. P. CudA. 1994. Host range of the mesquite cutworm, Melipotis indomita (Lepidoptera: Noctuidae), a potential biocontrol agent for mesquite (Prosopis spp.). Biological Control 4:38-44.

Dobson, G. E. 1878. Catalogue of the Chiroptera in the collection of the British Museum. British Museum (Natural History). London, United Kindom.

DunkLe, S. W., AND J. J. Belwood. 1982. Bat depredation on Odonata. Odonatologica 11:225-229.

Emrich, M. A., E. L. Clare, W. O. C. Symondson, S. E. Koenig, and M. B. Fenton. 2013. Resource partitioning by insectivorous bats in Jamaica. Molecular Ecology 23:3648-3656.

Fuint, M. L. 1985. Corn earworm, Heliothis zea. Pp. 51-55 in Integrated Pest Management for Cole crops and Lettuce. University of California Publications 3307. Oakland, EE. UU.

Freeman, P. W. 1981. Correspondence of food habits and morphology in insectivorous bats. Journal of Mammalogy 62:166-173.

Gardner, A. L. 1977. Feeding habits. Pp.293-350 in Biology of bats of the NewWorld Family Phyllostomidae. Part II (Baker, R. J., J. Knox Jones, Jr., and D. C. Carter, eds.). Special Publications. The Museum, Texas Tech University 13:1-364.

Griffiths, D. 1980. Foraging costs and relative prey size. The American Naturalist 116:743-752.

Hammer, Ø. 2015. PAST3 Paleontological Statistics Reference Manual. Natural History Museum, University of Oslo. Oslo, Norway.

Hewitt, G. B. 1977. Review of forage losses caused by rangeland grasshoppers. USDA Miscellaneous Publications 1348:1-24.

Hoffmeister, D. F. 1986. Mammals of Arizona. The University of Arizona Press and the Arizona Game and Fish Department. Tucson, EE. UU.

Hoy, R. R. 1992. The evolution of hearing in insects as an adaptation to predation by bats. Pp. 115-129 in The Evolutionary Biology of Hearing (Webster, D., R. Fay, and A. Popper, eds.). The Evolutionary Biology of Hearing. Springer Verlag. New York, EE. UU.

Jones, J. K., JR., And D. C. Carter. 1976. Annotated Checklist, with Keys to Subfamilies and Genera. Pp. 7-38 in Biology of bats of the New World family Phyllostomatidae. Part I. (Baker, R. J., J. K. Jones, Jr., and D. C. Carter, eds.). Special Publications No. 10. The Museum, Texas Tech University.

MagurRan, A. E., AND B. J. McGill. 2011. Biological Diversity: Frontiers in measurement and assessment. Oxford University Press. Oxford, United Kindom.

McCarthy, T. J. 1982. Bats records from the Caribbean lowlands of El Peten, Guatemala. Journal of Mammalogy 63:683-685.

McCRACKen, G. F. 1996. Bats aloft: a study of high-altitude feeding. Bat Conservation International Newsletter 14:7-10.

Medellín, R. A., H. T. Arita, And O. Sánchez. 1997. Identificación de los murciélagos de México. Clave de campo. Publicaciones especiales No. 2, Asociación Mexicana de Mastozoología, A. C. Ciudad de México, México.

Mintzer, A. 1979. Foraging activity of the Mexican leafcutting ant Atta mexicana (F. Smith) in a Sonoran Desert habitat (Hymenoptera: Formicidae). Insectes Sociaux (Paris) 26:364--372.

Murray, K. L., E. Fraser, C. Davy, T. H. Fleming, and M. B. Fenton. 2009. Characterization of the Echolocation Calls of Bats from Exuma, Bahamas. Acta Chiropterologica 11:415-424.

Osburn, W. 1865. Notes on the Chiroptera of Jamaica. Proceedings of Zoology of Society of London 1865:61-85. 
Ross, A. 1967. Ecological aspects of the food habits of insectivorous bats. Proceedings Western Foundation of Vertebrate Zoology 1:205-263.

Schondube, J. E., L. G. Herrera-M., and C. Martínez del Rıo. 2001. Diet and the evolution of digestion and renal function in phyllostomid bats. Zoology 104:59-73.

Segura-Trujillo, C. A., W. Z. Lidiker, Jr., and S. T. Álvarez-Castañeda. 2016. New perspectives on trophic guilds of arthropodivorous bats in North and Central America. Journal of Mammalogy 97: DOI: http://dx.doi.org/10.1093/jmammal/gyv212.

SiH, A., And B. Christensen. 2001. Optimal diet theory: when does it work, and when and why does it fail? Animal Behaviour 61:379-390.

Simmons, N. B. 2005. Order Chiroptera. Pp. 312-529 in Mammal species of the World: a taxonomic and geographic reference, Third Edition, Volume 1 (Wilson, D. E., and D. M Reeder, eds.). Johns Hopkins University Press. Baltimore, EE. UU.

Sмiтн, M. R. 1963. Notes on the leaf-cutting ants Atta sp. of the United States and Mexico. Proceedings of the Entomological Society of Washington 65:299-302.

Tuskes, P. M., J. P. Tuttre, ANd M. M. Coluins. 1996. The wild silk moths of North America. Comstock Publications Associates of Cornell University Press. Ithaca, EE. UU.

Villa-Ramírez, B. 1967. Los Murciélagos de México. Instituto de Biología, Universidad Nacional Autónoma de México. Ciudad de México, México.

Wiluams, C. B. 1935. The times of activity of certain nocturnal insects, chiefly Lepidoptera as indicated by a light trap. Transactions of the Royal Entomological Society of London 83:523-555.

WILson, D. E. 1973. Bat faunas: a trophic comparison. Systematic Zoology 22:14-29.

Woodruff, R. E., AND B. M. Beck. 1989. The scarab beetles of Florida (USA) (Coleoptera: Scarabaeidae) Part II. The May or June beetles (Genus Phyllophaga). Arthropods of Florida and Neighboring land areas. Gainesville, EE. UU.

Zamudio, S. 1984. La vegetación de la Cuenca del Río Estórax, en el Estado de Querétaro y sus relaciones fitogeográficas. Tesis profesional, Facultad de Ciencias, UNAM. Ciudad de México, México.

Submitted: November 5, 2015

Reviewed: January 12, 2015

Accepted: January 26, 2016

Associated editor: Consuelo Lorenzo 
MACROTUS WATERHOUSII FOOD IN CENTRAL MEXICO

178 THERYA Vol.7 (1): 161-177 